未来社会創造事業 探索加速型

「地球規模課題である低炭素社会の実現」領域

終了報告書(探索研究)

平成29年度採択研究開発代表者

\title{
[研究開発代表者名：本田 孝祐]
}

[国立大学法人 大阪大学 生物工学国際交流センター・教授]

(国立大学法人 大阪大学 大学院工学研究科・准教授)

\section{[研究開発課題名 :}

複合微生物群集の合理的設計による有機性廃棄物の二次資源化]

実施期間 ： 平成29年11月 1 日～令和 2 年3月 31 日 


\section{§1. 研究実施体制}

(1)「大阪大学」グループ

(1)研究開発代表者：本田 孝祐（大阪大学 生物工学国際交流センター、教授）

(2)研究項目

・好熱性アセトジェンの代謝改変による混合ガスからのエタノール生産

・有機物/混合ガス同時利用型アセトジェンの育種

•付加体由来菌叢と好熱性アセトジェンの共培養試験

・有機物/混合ガス同時利用型アセトジェンによる 1-ブタノール生産 (未着手)

・人工菌叢によるエタノールおよび1-ブタノール生産(未着手)

(2)「静岡大学」グループ

(1) 主たる共同研究者：木村 浩之（静岡大学グリーン科学研究所、教授）

(2)研究項目

·付加体由来污泥消化菌叢の探索

•多様な有機性廃棄物を利用可能な付加体由来菌叢ライブラリーの構築 (未着手)

(3)「京都大学」グループ(研究機関名)

(1)主たる共同研究者：跡見 晴幸（京都大学大学院工学研究科、教授）

(2)研究項目

•付加体由来モデル菌叢中の代謝マップの作製

・人工菌叢中の代謝マップの作製 (未着手)

\section{§ 2. 研究実施の概要}

本課題は、西南日本の太平洋側に広く分布する付加体と呼ばれる堆積層に由来するメタン発酵菌叢を利用 し、下水污泥等の有機性廃棄物を高付加価值な化学品へと転換するための新規技術を開発することを目的とし

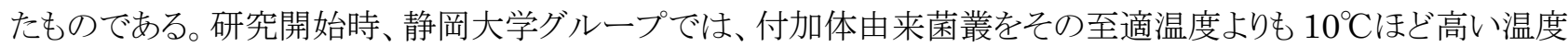
域で培養した場合、本来の生産物であるメタンではなく、その前駆体である水素 $\left(\mathrm{H}_{2}\right)$ ・二酸化炭素 $\left(\mathrm{CO}_{2}\right)$ の混 合ガスが生産される現象を見出していた。この現象に着目し、本課題では、有機性廃棄物を生育基質とした付 加体由来菌叢の高温培養で $\mathrm{H}_{2} / \mathrm{CO}_{2}$ 混合ガスを生産させると同時に、 $\mathrm{H}_{2} / \mathrm{CO}_{2}$ 混合ガスを種々の代謝物へと変 換可能な微生物をこれに組み合わせることで、多様な代謝物を生産することを目論んだ。

静岡大学グループでは、静岡県内の複数の地下温水掘削井から得られる付加体由来菌叢を用いて下水污 泥を生育基質とした培養試験を行った。この結果、異なる地点から採取した菌叢のいずれにおいても、これまで の知見と同様、高温培養時に $\mathrm{H}_{2} / \mathrm{CO}_{2}$ 混合ガスが生成されることが確認された。また培養器ヘッドスペースのガ スを断続的に置換するなどの操作を施すことによって、一般的なメタン発酵プロセスと比較して約 $70 \%$ のガス発 生速度と污泥減容化率を達成することができた。

大阪大学グループでは、 $\mathrm{H}_{2} / \mathrm{CO}_{2}$ 混合ガスを多様な代謝物へと変換可能な微生物として、好熱性アセトジェ ンである Thermoanaerobacter kivui に着目し、その培養と育種試験に取り組んだ。T. kivui は $\mathrm{H}_{2} / \mathrm{CO}_{2}$ 混合 
ガスを生育基質として独立栄養的に増殖できる一方で、有機物を含む培地上で従属栄養的な増殖を行うことも 可能な細菌である。本研究ではまず、 $\mathrm{H}_{2} / \mathrm{CO}_{2}$ と有機物 (グルコース)が共存する培養条件下で、本菌の独立栄 養的および従属栄養的代謝が互いに抑制 (カタボライト抑制)を引き起こすか否かについて検証を行った。この 結果、本菌の独立栄養的および従属栄養的代謝反応は目立った抑制効果を及ぼしあうことはなく、T. kivui は 有機物が共存する条件下であっても $\mathrm{H}_{2} / \mathrm{CO}_{2}$ を基質として生育可能であることが示された。また、静岡大学グル ープにより取得された付加体由来菌叢のうち、川根温泉 (静岡県島田市) 由来の菌叢を用いた試験により、同菌 叢が有機物 (グルコース、ペプトン、酵母エキス)から生産する $\mathrm{H}_{2} / \mathrm{CO}_{2}$ を基質として T. kivui が増殖可能であり、 その培養液中には本菌の主たる代謝産物である酶酸が蓄積することが示された。また、T. kivui に酢酸以外の 多様な代謝産物を生産させるべく、本菌の代謝改変試験に取り組んだ。プラスミド型ベクターならびに相同組換 えによる T. kivui のゲノム DNA への外来遺伝子の導入によるエタノール生産株の作成を試みた。しかしなが ら、いずれの手法を用いた場合も目的とした遺伝子導入を認めることはできず、本菌の代謝改変には至らなか つた。

京都大学グループでは培養温度の変化に伴う付加体由来菌叢内の代謝変化を明らかにすべく、菌叢解析 ならびに RNA Seq を用いたトランスクリプトーム解析を実施した。川根温泉由来菌叢を用いた継代培養実験の

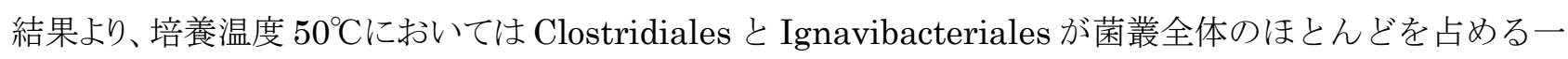
方で、培養温度を $60^{\circ} \mathrm{C}$ 高めた場合、Thermoanaerobacteriales が優先化する様子が認められた。また $50^{\circ} \mathrm{C}$ で培養を行った場合にはこれらに加え Methanobacteriales が検出された。トランスクリプトーム解 析では、 $50^{\circ} \mathrm{C}$ 培養の菌叢より methanofuran dehydrogenase を始めとするメタン生成に寄与する遺伝 子群の発現が確認された。培養温度 $60^{\circ} \mathrm{C} て ゙$ 特異的に発現する遺伝子は見出されなかったが、水素吸収型 ヒドロゲナーゼ遺伝子が高い発現量を示し、水素を利用する遺伝子群が活発化していることが示唆され た。これらの結果は、培養温度の変化に伴う付加体由来菌叢からの発生ガス種の変化が遺伝子の発現レ ベルの変化からも説明可能であることを示すものである。

主な発表論文

Matsushita M et al. (2018) Microbes Environ, 33:205-213

Sato Y, Kimura H (2019) Antonie Van Leeuwenhoek, 112:187-201

Matsushita M et al. (2020) Microbes Environ, in press (doi: 10.1264/jsme2.ME19103) 